\title{
PROXIMATE ANALYSIS AND PHYTOCHEMICAL AND MINERAL CONSTITUENTS IN FOUR CULTIVARS OF YAMS AND TUBER CROPS IN SRI LANKA
}

\author{
Senanayake $\mathrm{SA}^{1 *}$, Ranaweera KKDS ${ }^{1}$, Bamunuarachchi $\mathrm{A}^{1}$ and Gunaratne $\mathrm{A}^{2}$ \\ ${ }^{1}$ Department of Food Science and Technology, Faculty of Applied Sciences, University of Sri Jayewardene- \\ pura, Nugegoda, Sri Lanka ${ }^{2}$ Department of Agriculture, University of Sabaragamuwa, Belihuloya, Sri Lanka
}

Accepted: 22 March 2011

\begin{abstract}
A study was carried out to determine the levels of starch, protein, crude fat, crude fibre, ash and a few phytochemical constituents (saponins, flavanoids and alkaloids) and mineral elements (Calcium, Magnesium, Iron, Potassium and Zinc) in four cultivars of yams and tubers cultivated under similar agro-climatic conditions in Sri Lanka. Tubers of Dioscorea alata (Rajala and Hingurala), Dioscorea esculenta (Kukulala) and Xanthosoma sagittifolium (Kiriala) were subjected to the above analyses. The total starch percentage in crude flours ranged between $74.66 \pm 0.66$ to $80.46 \pm 0.62 \%$ on dry weight basis and no significant difference found in total starch $(P<0.05)$ between the studied varieties. The protein level ranged from $2.66 \pm 0.21$ to $10.16 \pm 0.64 \%$ whereas $D$. alata was found to contain a higher protein level. The crude fat levels in tubers varied ranging from $1.5 \pm 0.2$ to $2.3 \pm 0.1 \%$ and the highest level was observed in Xanthosoma sp. The crude fibre content in tubers was found to range from $1.8 \pm$ 0.1 to $2.33 \pm 0.15 \%$ and the highest level was observed in $D$. esculenta and the ash level ranged from $1.66 \pm 0.21$ to $2.33 \pm 0.21 \%$. There was no significant difference $(P<0.05)$ between the total starch in the extracted starch from the tubers and ranged from $86.3 \pm 1.2$ to $89.85 \pm 1.11 \%$. Crude saponin levels were significantly higher $(\mathrm{P}<0.05)$ in yams while $D$. alata and $X$. sagittifolium contained a level which was comparable $(P>0.05 ; 12.98 \pm 0.61$ and13.11 $\pm 0.52 \mathrm{mg} / 100 \mathrm{~g}$. High amount of flavonoids were observed in $D$. esculenta and $X$. sagittifolium $(12.4 \pm 0.46$ and $11.26 \pm 0.46 \mathrm{mg} / 100 \mathrm{~g})$. A considerable level of alkaloids was present in $D$. alata and $D$. esculenta $(1.640 .04 \pm \mathrm{mg} / 100 \mathrm{~g}$ and $1.89 \pm 0.02$ $\mathrm{mg} / \mathbf{1 0 0 g}$ ). All three cultivars of yams were rich in Calcium and Iron while a high level of Magnesium was observed in Xanthosoma sp $(45.27 \pm 0.31 \mathrm{mg} / 100 \mathrm{~g})$. High levels of Potassium were observed in all the samples.
\end{abstract}

Key words: Chemical composition, Dioscorea, Starch, Phytochemical, Yams, Xanthosoma sp

\section{INTRODUCTION}

Yams and tuber crops are efficient solar energy transferors and a very good source of starch which can be cultivated under less favourable conditions with minimum amount of agricultural inputs. These crops are grown in the tropical regions and consumed as primary, secondary or supplementary staple. Yams and tuber crops can be eaten boiled, roasted, fried or cooked. Dioscorea alata and Dioscorea esculenta are the two main yam species commonly found in Sri Lanka while Xanthosoma sagittifolium (Kiriala) species is also commonly consumed since its availability throughout the year. Although Dioscorea (Family: Dioscoreaceae) is a genus consisting of 630 identified species, nearly about 40 Dioscorea varieties are grown in Sri Lanka (Jayasuriya, 1995).

\footnotetext{
*Corresponding author: surajisena@gmail.com
}

The base of the Dioscorea esculenta (Kukulala) stem contains a large number of tubers which are generally ovoid and cylindrical (Fig. 1). Kukulala is widely cultivated in Sri Lanka, due to its flavour and short maturity period. The fleshy underground stem of Dioscorea alata (Rajala and Hingurala) contains only a single large tuber per vine. Dioscorea are seasonal crops and generally planted in the end of March to April. With the signs of yellowing leaves and withered vines mature crop is usually ready to harvest around December to February.

Starch is the main component in the yams (60 $-85 \%$ dry basis) and forms an important component in the diet of individuals living in rural areas of Sri Lanka (Jayakody et al, 2007). Xanthosoma spp are commonly known as new cocoyams (Kiriala) and the immature stems of the studied variety contains a red line on the 


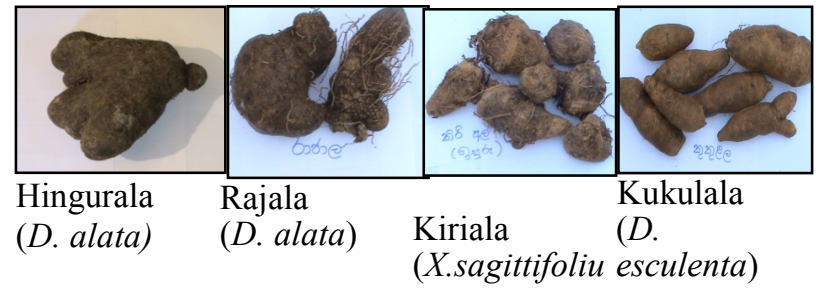

Figure 1: Morphology of yams and Xanthosoma spp

either side of the stem and the leaves contain blue- green pigments. A corm is produced at the base of the plant and this bears 10 to 15 lateral cormels (Kay, 1973)

After harvesting, these tuber crops upon passing a certain dormancy period may make sprouts if favourable conditions are met. This will bring a considerable amount of dry matter and water loss (Onwueme, 1982). However, if the tubers are properly stored these tubers can be made available throughout the year.

Yams (Dioscorea sp) and Xanthosoma sagittifolium (Kiriala) can be considered as nutritionally important tuber crops because of their high energy contribution as in the form of starch and raw yam provides about $494 \mathrm{KJ}$ (118 Kcal/100 g serving) (USDA Nutrient Database). These yams and tubers also contain various types of phytochemicals. The most predominant phytochemical characteristic of yam is the diosgenin saponin and dioscorine alkaloid. Although dioscorine and diosgenin are considered as toxic, such toxicity can be removed by washing, boiling and cooking (Eka, 1998). Diosgenin saponin can be used in the production of important steroids for human. The bitterness and toxicity of various wild yams are believed to be due to the alkaloid content. Certain flavonoids in these tubers may sometimes act as antioxidants and can oxidize LDL (Low Density Lipoprotein), prevent incidents of arteriosclerosis and heart disease.

Efficient supply of nutrients (macro and micro) in human diet is essential in maintaining the healthy lifestyle of man. This study was aimed to assess the chemical composition of crude flours and starches and to investigate the availability of some phytochemicals (saponin, flavanoid and alkaloid) and a few mineral constituents in four different cultivars; two species of Dioscorea (D. alata and $D$. esculenta) and Xanthosoma sagittifolium cultivated under similar agro - climatic conditions in Sri Lanka. Flour and starch samples were prepared two days after harvesting in order to understand the nutritional significance, but for a more conclusive study further examination of various samples of these cultivars cultivated under similar conditions from different regions and sites of Sri Lanka would need to be examined.

\section{MATERIALS AND METHODS}

Materials: Matured tubers of Dioscorea alata (Rajala and Hingurala), Dioscorea esculenta (Kukulala) and Xanthosoma sagittifolium (Kiriala) samples were randomly selected from the fields of the Horticultural Crop Research \& Development Institute, Gannoruwa, Sri Lanka. Flour and starch samples were prepared two days after harvesting.

Flour preparation: About $5 \mathrm{~kg}$ of the tubers were washed, hand peeled and trimmed to remove defective parts. Then the tubers were grated into thin chips $(\sim 5 \mathrm{~mm})$ and dried in an air convention oven at $40^{\circ} \mathrm{C}$ for $30 \mathrm{~h}$ up to $14 \%$ moisture. The dried chips were powdered using a laboratory scale grinder (Sumeet $\mathrm{CM} / \mathrm{L}$ $2128945)$ and sifted through $300 \mu \mathrm{m}$ sieve. The flour samples were sealed and packed in air tight containers for further analysis. (Maria et al, 2002)

Starch extraction: Starch separation was carried out according to the method described by Gunaratne (2007). Nearly about $3 \mathrm{~kg}$ of fresh tubers and yams were washed, peeled and diced and dipped in ice water containing $100 \mathrm{ppm}$ sodium metabisulphite to avoid browning. Homogenized at low speed in a laboratory scale blender (Sumeet $\mathrm{CM} / \mathrm{L}$ 2128945). The slurry was filtered through a filtering cloth using a small amount of water. Filtrate was centrifuged at $3,000 \mathrm{x}$ g for 10 minutes. The supernatant and the amber brown layer of protein on the surface of the sediment were removed and further purification was achieved by repeated suspension in water and centrifugation. The purified starch was dried at $35^{\circ} \mathrm{C}$ for $30 \mathrm{~h}$, sealed and packed for analysis.

Chemical analysis of extracted components: Moisture, lipid, protein ( $\mathrm{N} \times 6.25)$, ash and 
fibre were determined according to AOAC (1980) methods. Starch content was estimated by complete acid hydrolysis method. Flour sample of $2.5 \mathrm{~g}$ was suspended in a mixture of $200 \mathrm{ml}$ of water and $20 \mathrm{ml}$ of $\mathrm{HCl}$ acid. (Sp. Gravity 1.125) The mixture was heated in a flask provided with a reflux condenser for 2.5 hours. Contents were cooled, neutralized with $\mathrm{NaOH}(5 \mathrm{~N})$. Volume was made to $250 \mathrm{ml}$ and the sugar formed was determined as dextrose by Lane and Eynon reducing sugar estimation method. The dextrose multiply by 0.9 was taken as starch.

Mineral composition and starch granular structure: Mineral elements $(\mathrm{Ca}, \mathrm{Mg}, \mathrm{Fe}, \mathrm{K}$ and $\mathrm{Zn}$ ) were determined by dry ashing method, (AOAC 1980) followed by elemental analysis by Atomic Absorption Spectrophotometer (GBC Avanta Ver 1.33). Structure of starch granules were observed under (10 X 100) light microscope (Magnus MLX-DX).

Phytochemical composition: Phytochemicals were determined gravimetrically with slight modifications to the methods described by Okwu D.E and C. U Nadu (2006).

Crude saponin determination: A sample of $2.5 \mathrm{~g}$ of flour was dispersed in $25 \mathrm{ml}$ of $20 \%$ ethanol. The suspension was heated over a hot water bath at $55^{\circ} \mathrm{C}$ for $4 \mathrm{~h}$ with continuous stirring. The mixture was filtered and the residue re- extracted twice with another $25 \mathrm{ml}$ of ethanol. The combined extracts were reduced to one quarter of the total volume by heating over a water bath maintained at $90^{\circ} \mathrm{C}$ (Okwu D.E, 2006). The aqueous portion of the concentrate was extracted thrice with $20 \mathrm{ml}$ of diethyl ether by using a $250 \mathrm{ml}$ separating funnel. The extract was purified further with $40 \mathrm{ml}$ of n-butanol and washed thrice with $5 \%$ aqueous $\mathrm{NaCl}$. The remaining solution was evaporated at $95^{\circ} \mathrm{C}$ over a water bath until obtaining a constant weight. The saponin content was calculated on dry basis.

Crude flavonoid determination: A sample of $1 \mathrm{~g}$ flour sample was mixed with $20 \mathrm{ml}$ of $80 \%$ aqueous methanol and extracted flavonoids at room temperature by using an ultra sonic bath for 30 minutes. The solution was filtered through Whatman filter paper No. 42 (12mm).
The filtrate was evaporated on a boiling water bath until a constant weight was obtained. The flavonoids were calculated on dry matter basis (Okwu D.E, 2006).

Crude alkaloid determination: A sample of 1 $\mathrm{g}$ flour was taken to $100 \mathrm{ml}$ beaker and $50 \mathrm{ml}$ of $20 \%$ acetic acid in ethanol was added and covered to stand for $4 \mathrm{~h}$. Contents were filtered and concentrated using a water bath at $100^{\circ} \mathrm{C}$ until one - quarter of its original volume. Concentrated Ammonium was added drop wise until a maximum precipitate was achieved. Contents were dried at $70^{\circ} \mathrm{C}$ until obtaining a constant weight. Alkaloid content was calculated on dry matter basis (Okwu, 2006).

Statistical analysis: Samples were analysed in replicates of three (3) and values were evaluated using the One - Way ANOVA Tukey's test $(\mathrm{P}<0.05)$.

\section{RESULTS AND DISCUSSION}

Proximate analysis of flours: The results indicate that the Xanthosoma sp (Kiriala) is slightly richer in starch than the studied yam varieties (Table 1). From the three yam varieties though Hingurala contained a higher level of starch on dry weight basis there was no significant difference $(\mathrm{P}<0.05)$ in the starch content of the studied cultivars. Yams contained a higher level of proteins compared to the Xanthosoma sp. Dioscorea alata (Rajala) contained the highest level of proteins (10.16 \pm $0.64 \%$ ). Crude fat content was higher in the Xanthosoma sp $(2.3 \pm 0.1 \%)$ while there was no significant difference $(P>0.05)$ in the crude fat content of yams.

Crude fibre levels were comparatively high in kukulala and Kiriala while Hingurala contained the lowest. Kiriala and Hingurala indicated a higher level of ash while Rajala contained a lower level. This study showed that the fat and ash contents for all the flours tested were higher than those have been reported in the literature. i.e.: ash and fat contents in different varieties of $D$. alata $0.19-0.51 \%$ and 0.5 $0.73 \%$ respectively (Riley et al, 2006). However, these differences can be expected due to varietal and geographical differences. High amounts of fat can be one of the reasons for the feeling of satiety once consumed these 
Table 1: Chemical composition of flours and starches of yams and Xanthosoma sp (\% dry weight basis)

\begin{tabular}{|c|c|c|c|c|c|}
\hline Source & $\begin{array}{l}\text { Total } \\
\text { starch }\end{array}$ & Protein* & $\begin{array}{l}\text { Crude } \\
\text { fat }\end{array}$ & $\begin{array}{l}\text { Crude } \\
\text { fibre }\end{array}$ & Ash \\
\hline \multicolumn{6}{|l|}{ Flours } \\
\hline D. alata & $75.86 \pm$ & $10.16 \pm 0$ & $1.53 \pm 0$ & $2.0 \pm 0$ & $1.66 \pm 0$ \\
\hline (Rajala) & $2.01^{\mathrm{a}}$ & $.64^{\mathrm{a}}$ & $31^{b}$ & $1^{\mathrm{b}}$ & .21 \\
\hline D. alata & $78.32 \pm$ & $6.24 \pm 0$ & $1.56 \pm 0$. & $1.8 \pm 0$. & $2.33 \pm 0$ \\
\hline (Hingurala) & $1.14^{\mathrm{a}}$ & 26 & & $1^{\mathrm{b}}$ & $.15^{\mathrm{a}}$ \\
\hline D. esculenta & $74.66 \pm$ & $9.02 \pm 0$ & $1.5 \pm 0.2$ & $2.33 \pm 0$ & $2.1 \pm 0$. \\
\hline (Kukulala) & $0.66^{\mathrm{a}}$ & 65 & & $.15^{\mathrm{a}}$ & $2^{a}$ \\
\hline$X$. sagittifolium & $80.46 \pm$ & $2.66 \pm 0$ & $2.3 \pm 0.1$ & $2.13 \pm 0$ & $2.33 \pm 0$ \\
\hline (Kiriala) & $0.62^{\mathrm{a}}$ & 21 & & $.15^{\mathrm{b}}$ & $.21^{\mathrm{a}}$ \\
\hline \multicolumn{6}{|l|}{ Starch } \\
\hline D. alata & $86.81 \pm$ & $2.1 \pm 0.0$ & $0.43 \pm 0$. & n.dt & $0.33 \pm 0$ \\
\hline (Rajala) & 1.83 & $9^{f}$ & $06^{\mathrm{i}}$ & & $.01^{\mathrm{k}}$ \\
\hline D. alata & $86.61 \pm$ & $2.02 \pm 0$ & $0.41 \pm 0$ & n.dt & $0.41 \pm 0$ \\
\hline (Hingur & $1.56^{\mathrm{e}}$ & $11^{\mathrm{f}}$ & $02^{i}$ & & $.01)^{\mathrm{j}}$ \\
\hline culenta & $86.3 \pm 1$ & . $1.2 \pm 0.0$ & $0.42 \pm 0$ & n.dt & $0.25 \pm 0$ \\
\hline & & $1^{\mathrm{g}}$ & $01^{\mathrm{i}}$ & & $.01)^{1}$ \\
\hline ifolium & l $89.85 \pm$ & $1.12 \pm 0$. & $0.63 \pm 0$. & n.dt & $0.31 \pm 0$ \\
\hline (Kiriala & 1.11 & & $04^{\mathrm{h}}-{ }^{-}$ & & $.02)^{\mathrm{k}}$ \\
\hline
\end{tabular}

$\mathrm{N}^{*} \mathrm{X} 6.25$, Data represent the mean of three replicates.

Values followed by the different superscript in each column are significantly different $(\mathrm{P}<0.05)$

n.dt $=$ not determined

cultivars compared to other root and tuber crops such as cassava, potato and sweet potatoes.

The highest level of extracted starch was observed in Kiriala and more protein was observed in Rajala and Hingurala $(2.1 \pm 0.09$ and $2.02 \pm 0.11 \%$ respectively). This may be probably due to the presence of mucilaginous material in starch. Fat content in Kiriala starch was comparatively higher $(P<0.05)$ than in yams while more ash was observed in Hingurala.

\section{Phytochemical composition: The} phytochemical composition of yams and Xanthosoma sp are shown in Table 2. The saponin and alkaloid contents are considered important due to their toxicity in certain yams and tubers. D. esculenta had the highest saponin content of $20.01 \pm 0.46 \mathrm{mg} / 100 \mathrm{~g}$ while D. alata (Rajala) contained the lowest level of saponin $(12.98 \pm 0.61 \mathrm{mg} / 100 \mathrm{~g})$. High amount of flavonoids were observed in D. esculenta and $X$. sagittifolium (Table 2). Although $D$. alata contained purple pigments low levels of flavonoid were observed compared to the other white varieties. In this study crude levels of flavonoids were measured and the molecular weights of the extracted flavonoids from white cultivars may be higher compare to the purple yam. Considerable level of alkaloids was present in Hingurala and Kukulala (1.64 \pm 0.04 and $1.89 \pm 0.02 \mathrm{mg} / 100 \mathrm{~g})$. The lowest level was in Rajala $(0.94 \pm 0.04 \mathrm{mg} / 100 \mathrm{~g})$. The

Table 2: Phytochemical composition of yams and Xanthosoma sp on dry weight basis (mg/100g)

\begin{tabular}{|c|c|c|}
\hline $\begin{array}{l}\text { Botanical } \\
\text { name }\end{array}$ & $\begin{array}{l}\text { Local } \\
\text { name }\end{array}$ & Flavonoids Alkaloids \\
\hline D. alata & Rajala & $12.98 \pm 0.61^{\mathrm{c}} 5.19 \pm 0.15^{\mathrm{d}} 0.94 \pm 0.04^{\mathrm{c}}$ \\
\hline D. alata & Hingurala & $\mathrm{a} 18.24 \pm 0.15^{\mathrm{b}} 9.84 \pm 0.26^{\mathrm{c}} 1.64 \pm 0.04^{\mathrm{b}}$ \\
\hline D.esculen & Kukulal & $20.01 \pm 0.26^{\mathrm{a}} 12.4 \pm 0.46^{\mathrm{a}} 1.89 \pm 0.02^{\mathrm{a}}$ \\
\hline $\begin{array}{l}\text { X.sagittifo } \\
\text { um }\end{array}$ & Kiriala & $13.11 \pm 0.52^{\mathrm{c}} 11.3 \pm 0.46^{\mathrm{b}} 0.99 \pm 0.01^{\mathrm{c}}$ \\
\hline
\end{tabular}

Data represent the mean of three replicates, Values

followed by the different superscript in each column are significantly different $(\mathrm{P}<0.05)$

availability of high levels of alkaloids in tubers causes itchiness, bitterness and/or sometimes toxicity (Oliver- Bever 1989).

Mineral composition and starch granular structure: All three varieties of yams werefound to be rich in Calcium and Iron while a high level of Magnesium was observed in Kiriala (Table 3). High levels of Potassium were observed in all the samples. Usage of Potassium rich fertilizers can be of one of the causes to this. All the samples contained lower levels of Zinc compared to analyzed mineral matter. Literature reveals very low levels of

Table 3: Mineral content of different varieties of yams and Xanthosoma sp on dry weight basis $\left(\mathrm{mg}^{100 \mathrm{~g}^{-1}}\right)$

\begin{tabular}{|c|c|c|c|}
\hline Source & $\begin{array}{l}\text { Calciu } \\
\mathrm{m}\end{array}$ & Iron $\mathrm{Ma}$ & Zinc \\
\hline D. alata & $8.13 \pm$ & $2.29^{\mathrm{a}} 206.9$ & $1.07 \pm$ \\
\hline 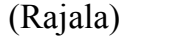 & $0.05^{\mathrm{a}}$ & $0.11^{\mathrm{b}}$ & $0.05^{\mathrm{a}}$ \\
\hline D. alata & 8.15 & $16^{\mathrm{b}} 184.21 \pm$ & $2.11 \pm$ \\
\hline (Hi & $\pm 0.29^{\mathrm{a}}$ & $0.2^{\mathrm{a}}$ & $0.1^{b}$ \\
\hline ulenta & $8.29 \pm$ & $6.12 \pm 33.6 \pm 1.19^{\mathrm{a}} 190.91 \pm$ & $1.19 \pm$ \\
\hline & $0.06^{\mathrm{a}}$ & $0.03^{\mathrm{a}}$ & $0.08^{\mathrm{a}}$ \\
\hline Xanthos & $6.36 \pm$ & $.31^{c} 184.15 \pm$ & $1.16 \pm$ \\
\hline $\begin{array}{l}\text { sagittifolium } \\
\text { (Kiriala) }\end{array}$ & $0.31^{\mathrm{b}}$ & $0.31^{\mathrm{a}}$ & $0.15^{\mathrm{a}}$ \\
\hline
\end{tabular}

Data represent the mean of three replicates, Values

followed by the different superscript in each column are significantly different $(\mathrm{P}<0.05)$

minerals in Nigerian varieties of D.alata species (Okwu et.al, 2006). But further studies concerning the phytochemicals and mineral constituents of these varieties cultivated in different sites and regions of Sri Lanka is needed to come to a more conclusive study. Light microscopic view of extracted starches 


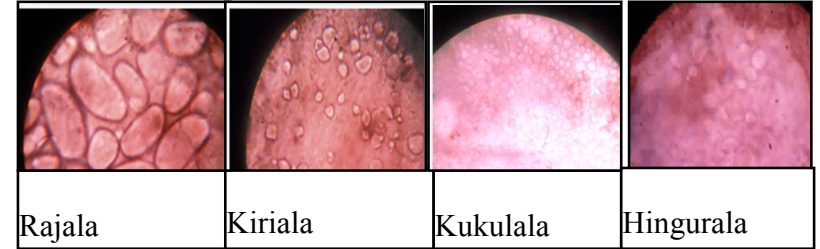

Figure 2: Light microscopic starch granular structure of yams and Xanthosoma spp (10 X 100)

(figure 2) showed that Kukulala contained comparatively smaller granules from the studied species and digestibility of starches with smaller granular sizes is fairly high (Szylit et al, 1978). Genetic variations and environmental conditions influence the structure and the properties of starch (Debon and Tester, 2000).

The starch granular shape of Dioscorea esculenta was polygonal and Rajala contained oval shaped granules. The largest granules were observed in Rajala while kukulala contained the smallest from the studied cultivars.

\section{CONCLUSION}

Flours obtained from yams and Xanthosoma sp contained a considerable level of starch as the main constituent on dry matter basis. More purification was needed to ensure the purity of extracted starch. Results revealed the presence of significant quantity of protein in yam flours. A considerable amount of crude fat was observed in the yams and Xanthosoma sp (latter being the highest). These cultivars also contain a significant quantity of crude fibre and ash. From the phytochemical constituents studied in yams and Xanthosoma sp, Kukulala contained a higher levels of saponins, flavanoids and alkaloids while Rajala contained the lowest level. There was no significant difference in the Calcium, Magnesium and Iron levels in the studied yam varieties and a considerably higher amount of Potassium was observed in Rajala. Zinc content was higher in Hingurala compared to other studied tubers. Further studies concerning the digestibility and availability of these nutrients and phytochemicals of these cultivars cultivated in different sites and regions of Sri Lanka is needed to come to a more conclusive study.

\section{REFERENCES}

Association of Official Analytical Chemistry (AOAC)1980 Official methods of analysis of AOAC International, Volume 1.

Debon SJJ and Tester RF 2000 "In vivo" and "In vitro" annealing of starches , Gums and stabilizers for the food industry, pp $270-276$.

Eka OU 1998 Roots and Tuber Crops in International quality of plant foods, Post harvest Research unit Publications, Univ - Benin: pp 131.

Gunaratne A 2007 The Journal of Cereal Chemistry, 84(1): $30-37$.

Jayakody L, Hoover R Liu Q and Donner E 2007 studies on tuber starches. II. Molecular structure, composition and physicochemical properties of yam Dioscorea $\mathrm{sp}$ ) starches grown in Sri Lanka, carbohydrate Polymers, 69: 148 - 163.

Jayasuriya AHM 1995 Dioscoreaceae In MD.Dissanayake (Ed), A revised handbook to the flora of Ceylon (Vol. IX: 47 -80)

Kay DE 1973 Root crops, TPI crop and product digest. $160-167$.

Maria V Grossmann, Rosa M Alves, Cristina F, Noemi N. Martino and Seirakoski MR 2002 Chemical and Functional Characterization of Products Obtained from Yam Tubers, Starch/ Srarke, Vol 54: 476- 481.

Modern Cereal Chemistry, $5^{\text {th }}$ edition by G. W. Kent Jones and A.J Amore.

Okwu DE and Nadu CU 2006 International Journal of Molecular Medicine and Advance Sciences 2 (2):199-203.

Oliver - Bever B 1989 Medicinal Plants in Tropical West Africa, Cambridge Uni. Cambridge, pp 70.

Onwueme IC 1982 The Tropical Tuber Crops Yams, Cassava, Sweet potato, Cocoyams, New York, USA, pp 3- 108

Riley CK Wheatly AO and Asemota HN 2006 African Journal of Biotechnology vol 5:15281536).

Szylit O DurandM, Borgida LP, Atinkpahoun H, Prieto, F and Delort-Laval J 1978 Raw and steam- pelleted cassava, sweet potato and yam cayenensis as starch sources for ruminant and chicken diets. Animal feed science technology, 3: $73-87$. 